\title{
Peer to Peer Lending Intention using TAM Perspective
}

\author{
Giovanni Fiorentino ${ }^{1}$, Evi Wiliana ${ }^{2}$, Panji Rahmat Sahid ${ }^{3}$, Willy Gunadi ${ }^{4}$ \\ ${ }^{1}$ Business Management, Management Department, Binus Business School Master Program, Bina Nusantara \\ University, Jakarta, Indonesia, giofiorentino2@gmail.com \\ ${ }^{2}$ Business Management, Management Department, Binus Business School Master Program, Bina Nusantara \\ University, Jakarta, Indonesia, eviwiliana7@ gmail.com \\ ${ }^{3}$ Business Management, Management Department, Binus Business School Master Program, Bina Nusantara \\ University, Jakarta, Indonesia, panjirahmatsahid@gmail.com \\ ${ }^{4}$ Business Management, Management Department, Binus Business School Master Program, Bina Nusantara \\ University, Jakarta, Indonesia, wgunadi@ binus.edu
}

\begin{abstract}
One of the technological developments that have been used increasingly is fintech or technology implementation related to financial activities. One area of fintech in Indonesia that is experiencing significant development is peer to peer lending which offers financial benefits by allocating funds for borrowers with technology as a support. This study looks for factors that cause potential investors to have the intention to lending money in order to do investing activities via peer to peer (P2P)lending platforms in Indonesia. By understanding the factors that influence the intention to perform $P 2 P$ lending, several actions can be taken by related parties to increase the number of $P 2 P$ platform lenders. This study is gathering data by collecting from 135 sample using judgmental sampling via non-contrived online questionnaire. Submitted data processed with PLS-SEM method via Smart PLS software. Perceived intermediary trust and perceived usefulness are two components from this study that have a significant impact for defining lender's intention to use P2P Lending.
\end{abstract}

Keywords:Financial Technology, Influencing Factors, Intention, Peer to Peer Lending, P2P,Technology Acceptance Model, Trust

\section{INTRODUCTION}

In recent years, many studies have examined the factors that influence the acceptance of IS or technology (Chuang et al., 2016; Huei et al., 2018; Lee, 2017). One of widely used theory is the Technology Acceptance Model (TAM). TAM is widely used in testing acceptance of a system because it's advantage that enable us to explain significant percentage of the variance of the factors (Sánchez-Prieto et al., 2017).However, significant factors that will affect the intention to use and accepting the system vary between systems (Bae \& Han, 2020).

One area of technology development that is growing in Indonesia in recent years is the development of technology in the financial services sector, commonly called 'fintech'. Fintech is a collection of financial activities that use technology that aims to improve the performance of financial activities (Schueffel, 2016). One of the fintech fields in Indonesia that is experiencing rapid development is peer to peer lending (P2P lending) sector. As of June 2019, in Indonesia, it was noted that the accumulated loans using P2P lending services amounted to Rp. 44,806 trillion, where this figure increased by $97 \%$ compared to the previous year (Financial Services Authority, 2019). In terms of the number of users, there are 498 thousand lenders and 9.7 million borrowers who use this service in Indonesia, and this figure increased by 120 percent over the previous period.

Although the prospect of financial benefits from P2P looks attractive, there is a risk that lenders have that is the possibility of credit default, where the risk will be borne entirely by the lender (Klafft, 2008). Besides, another factor that can cause losses in the P2P lending system is the possibility of losing funds caused by system failure due to fraud or cybercrime (Milne \& Parboteeah, 2016). Based on the risks that can occur, the trust factor is an important factor to study. Previous studies have shown that trust is a source of interpersonal and commercial relationships because trust is crucial where there is a risk in doing something (Salloum \& Al-Emran, 2018). In the context of P2P lending, the assessment of prospective lenders in trusting the system and prospective borrowers is a factor that needs to be analyzed in usingP2P lending platform. There are related studies that share trust with platforms and borrowers to measure the significance of these two factors (Chen et al., 2014). Apart from trust, some studies examine perceived benefit as a factor that influences the intention to lending moneyviaP2P lending platforms. The study states that perceived benefit is the main thing that prospective lenders pay attention to in lending funds (Ryu, 2018). Therefore, we will analyze perceived benefit as a significant factor and compare the results with the trust factor. 
In recent years, there have been several studies that use TAM as one of the basic theories in determining the level of user acceptance for a system in Indonesia. Some contexts that are often discussed in this study include the fields of e-learning and internet or mobile financial services (Tanduklangi, 2017; Sensuse \& Napitupulu, 2017; Radnan \& Purba, 2018). Research in Indonesia that deals with P2P lending currently mostly discusses legal protection issues related to $\mathrm{P} 2 \mathrm{P}$ lending lenders and the role of the government in overseeing the operations of P2P lending (Sari, 2018; Pramana et al. 2018; Abubakar \& Handayani, 2018). There is also research that takes the theme of P2P lenders in Indonesia, which seeks to finding out factors that influence one's interest in investing in P2P platform as a lenders (Puteri et al., 2018; Sukmaningsih, 2018; Sundjaja \& Tina, 2019; Tandiono et al., 2020). The difference between this research and the current research is the theory used. The previous study did not use TAM theory in analyzing the factors that influence one's interest in becoming a lender on P2P lending platforms.

Based on several findings related to previous research, it can be concluded that currently, no studies are examining the intention to use P2P lending using the TAM approach for the Indonesian market.

This study will be using modified TAM following the characteristics of $\mathrm{P} 2 \mathrm{P}$ lending in terms of lenders perspective as the basis of this study. The purpose of this study is to analyze critical factors that influence one's intention to invest as a lender on $\mathrm{P} 2 \mathrm{P}$ lending platforms in Indonesia.

\section{LITERATURE REVIEW}

\subsection{PEER TO PEER (P2P)}

Peer to peer $(\mathrm{P} 2 \mathrm{P})$ lending is an implementation of fintech in the form of online platform, where a borrower can be united with investors who want to lend funds (Hendriyani, 2019). In Indonesia, there are fintech transactions of US\$ 15 billion, of which as much as 15 percent is coming from lending activities (Faith, 2018). Some of the main advantages of P2P lending are the interest that is earned by individuals who lend money is higher than the interest offered by banks, and the ease of getting loans for individuals and MSMEs from the borrower side (Klafft, 2008). However, behind the convenience offered by $\mathrm{P} 2 \mathrm{P}$ lending, there is also a substantial risk of default, which is generally borne by those who lend funds. To overcome this, the $\mathrm{P} 2 \mathrm{P}$ lending platform generally acts as an intermediary who determines credit scoring to give brief assessment and analysis of whether prospective borrowers can return the funds that have been borrowed.

\subsection{TECHNOLOGY ACCEPTANCE MODEL}

Technology Acceptance Model (TAM) is a theory used to find out why someone accepts or refuses to use an information system (Davis, 1985). TAM is a theory that adapted from Theory of Reasoned Action that was made specifically with the emergence of the concept of information system at that time. According to this theory, factors that determine the acceptance of an information system by users are perceived ease of use and perceived usefulness. In 2000, there was a study that discussed Extended TAM, which is an adaptation of the TAM concept. In the Extended TAM model, factors that can have effecton perceived usefulness and perceived ease of use can be added depending on the context of the research conducted by the user (Venkatesh \& Davis, 2000). This study will use the variables perceived ease of use, perceived usefulness, and intention to use to analyze the factors to be tested.

\subsection{PERCEIVED EASE OF USE}

Perceived ease of use is the user's view of the ease of use of a system (Davis, 1985). Initially, a user may feel some difficulty to use a new system because the user does not have sufficient ability and confidence in using the system. After users feel more familiar with the system, most users will find using the system easier (Hackbarth et al., 2003). In the context of P2P lending, perceived ease of use can be demonstrated by how easy a user can find information or getting updates related to the process that is being run (Thaker et al., 2019).

\subsection{PERCEIVED USEFULNESS}

Perceived usefulness is the prospective user's perception of the user that can be obtained using the tested system (Davis, 1985). A system that has high perceived usefulness will be trusted by users as a system that can and will be used for the needs of users (Davis, 1989). Several studies shown that perceived usefulness holds important role in terms of acceptance of technology (Sohn, 2017; Mou et al., 2017). In the context of P2P lending, the more lenders convinced that the usingP2P lending can provide financial benefits as promised, the greater the value of perceived usefulness.

\subsection{ATTITUDE TOWARDS BEHAVIOR}

Attitude towards behavior is an element in TAM theory that measures the feelings of a subject in acting (Fathema et al., 2015; Weng et al., 2018; Wu \& Chen, 2017). Based on some TAM elements that have been discussed in the previous point, based on this assessment, an attitude towards action will be created (Van der Heijden et al., 2003). If potential users have a more positive attitude towards the use of a system, then the the intention to use the system will be higher (Davis, 1989).

\subsection{PERCEIVED INTERMEDIARY TRUST}

Perceived intermediary trust is a sense of trust that arises from prospective lenders to the $\mathrm{P} 2 \mathrm{P}$ lending platform to be used. Perceived intermediary trust is often used to measure platform trust like online marketplace (Wang et al., 2014). In several studies on $\mathrm{P} 2 \mathrm{P}$ lending, this factor is one type of trust that is tested (Yang \& Lee, 2016; Chen et al., 2014). Several things can affect trust in the platform; it is important to convince prospective lenders that the platform can run $\mathrm{P} 2 \mathrm{P}$ lending systems properly, and can meet the needs of users and provide protection for lenders (Chen et al., 2014). 


\subsection{PERCEIVED BORROWER TRUST}

Perceived borrower trust is a sense of trust that arises from prospective borrowers of funds. One study stated that interpersonal trust between lenders and borrowers is focused on research related to the success of P2P lending (Greiner \& Wang, 2010). The trust factor to the borrower is another factor that is often tested and compared with perceived intermediary trust (Puteri et al, 2018; Chen et al., 2014; Yang \& Lee, 2016). In general, a lender needs to be sure that the borrower will be able to return the borrowed funds and their interest according to agreed schedules and regulations (Chen et al., 2014)

\subsection{PERCEIVED BENEFITS}

Previous research shows that in choosing to use a service, a prospective lender will generally assess the advantages or benefits obtained from the product (Akturan \& Tezcan, 2012; Nanggong, 2019). Some advantages of P2P lending from the perspective of prospective lenders are security that is regulated by law, ease and speed in providing loans, and significant interest rates when compared to traditional institutions such as banks (Tampubolon, 2019). However, behind that, some risks need to be considered such as the risk of default and a low level of loan liquidity. In the context of $\mathrm{P} 2 \mathrm{P}$ lending, a prospective lender needs to be sure that investing in a $\mathrm{P} 2 \mathrm{P}$ platform can provide a large profit for the lender.

\section{HYPOTHESIS DEVELOPMENT}

To measure the level of intentions of action, we chose to use the Extended TAM model to measure the significance level from factors that can affecting the intention to use P2P lending systems from lenders perspective. Here we develop hypotheses using factors that have been tested on previous studies to measure the level of desire or purchasing decisions on financial products. These factors will affect the level of perceived ease of use and perceived usefulness, which will determine the value of attitudes toward actions and the level of intention to carry out these actions.

Previous studies have shown that perceived intermediary trust can influence perceived borrower trust (Puteri et al., 2018, Chen et al., 2014; Zhang et al., 2014). The studies show the view of prospective users that a good P2P lending platform can provide services in the form of a screening of prospective borrowers of funds which causes increased confidence in the borrowers of funds. Other research shows that trust in intermediaries can directly influence attitudes towards investment behavior as lenders onP2P lending platforms (Van der Heijden et al., 2003; Verhagen et al., 2006). Therefore, we will test following hypotheses:

Hypothesis 1 (H1): Perceived intermediary trust positively influences perceived borrower trust

Hypothesis 2 (H2): Perceived intermediary trust positively influences attitude towards using P2P platforms
There have been several previous studies which stated that perceived borrower trust can influence attitudes towards an action being tested (Lim et al., 2006; Limbu et al., 2012; Eastlick et al., 2006). According to the study, this relationship has been widely documented under various conditions (Lim et al., 2006). The greater the trust that is formed, the attitude towards these actions will be more positive. In the context of $\mathrm{P} 2 \mathrm{P}$ lending, level of trust in borrowers, in general, will affect attitudes towards investing in the P2P lending platform. Therefore, we will test the following hypothesis:

Hypothesis 3 (H3): Perceived borrower trust positively influences attitude towards using $\mathrm{P} 2 \mathrm{P}$ platforms

Previous research stated that perceived benefit is a factor that influences attitudes to invest in P2P lending platforms (Yang \& Lee, 2016). This is also supported by other research (Ryu, 2018; Lee, 2009). In the context of P2P lending, perceived benefit can be in the form of estimated benefits that can be obtained when compared to other investment products. Therefore, we test the following hypothesis:

Hypothesis4 (H4): Perceived benefit has a positive effect on attitude towards using $\mathrm{P} 2 \mathrm{P}$ platforms

In previous studies related to TAM, there is a conclusion that perceived ease of use affects the perceived usefulness and attitude of acceptance to the information system being tested (Venkatesh \& Davis, 2000). This is supported by several studies that used TAM in testing other financial products (Van der Heijden et al., 2003; Kleivene, 2018; Yu et al., 2018). In the P2P context, a studiy use this hypothesis as part of TAM (Lee, 2017). Based on that, we will test the following hypotheses:

Hypothesis 5 (H5): Perceived ease of use has a positive effect on perceived usefulness

Hypothesis 6 (H6): Perceived ease of use has a positive effect on attitude towards using P2P platforms

Perceived usefulness is part of the TAM theory that is considered to influence attitude to behavior (Davis, 1989). The relationship between these two variables has been proven in several previous studies (Lee, 2017; Amin \& Lee, 2014). Previous research states that perceived usefulness is one indicator that determines the use of technology in a sustainable manner (Lee et al., 2013). Therefore, this study will use the following hypotheses relating to perceived usefulness:

Hypothesis 7 (H7): Perceived usefulness has a positive effect on attitude towards using $\mathrm{P} 2 \mathrm{P}$ platforms

Based on the TAM theory, the more a person has a positive attitude towards an information system, the more likely that person will have the intention to use the system (Davis, 1989). Previous research states that attitude is the best predictive variable to measure the intention of using a technology (Teo $\&$ Zhou, 2014). Several recent studies that tested TAM in the 
fintech field also concluded the same thing (Suyanto \& Kurniawan, 2019; Chuang et al., 2016). Therefore, we will test following hypothesis:

Hypothesis 8 (H8): Attitude towards using P2P platforms positively influences the intention to use $\mathrm{P} 2 \mathrm{P}$ platforms

Figure 1 shows research models that will be used based on described hypothesis.

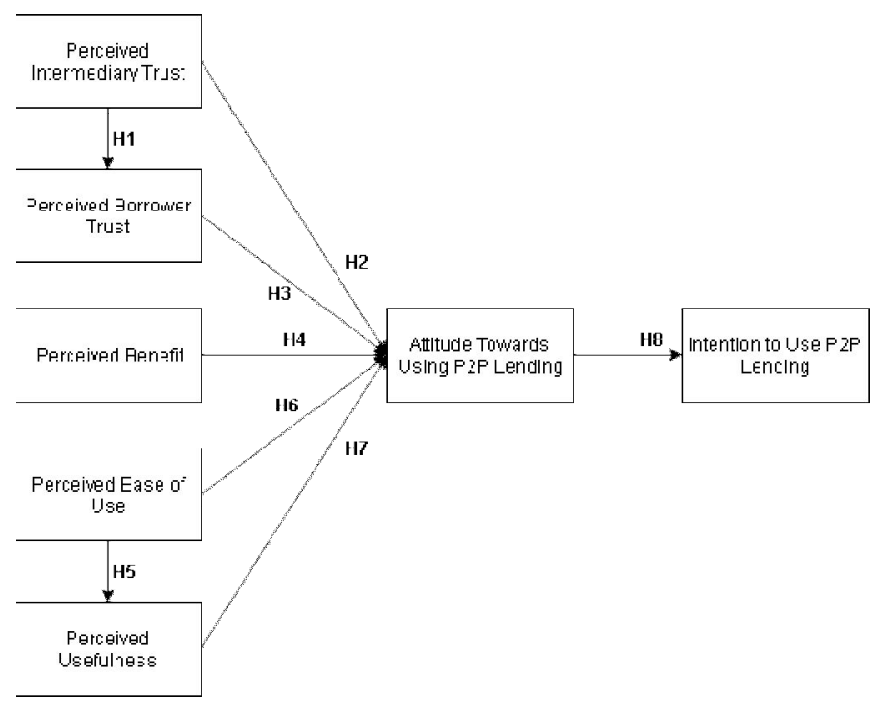

Figure 1: Research Model

\section{RESEARCH METHOD}

\subsection{MEASUREMENT}

A questionnaire was distributed online, with questions adapted from previous studies that measured matters relating to the variables of this study. Each variable tested in the research model was measured by as many as three items related to the variable (Kim et al., 2010; Pavlou et al., 2003). The questions can be seen in Appendix 1 of this study. The answers to these questions were measured using a five-point Likert scale, with a scale that ranged from 1 (Strongly Disagree) to 5 (Strongly Agree).

\subsection{DATA COLLECTION AND ANALYSIS}

In collecting data needed in research, the survey process was be carried out using a judgmental sampling approach to individuals who had used the $\mathrm{P} 2 \mathrm{P}$ lending platform as a lender, at least once in the last 1 year period, who were domiciled in Jakarta and the surrounding areas (Greater Jakarta). The selection of the Greater Jakarta area was taken because based on data on the distribution of lenders, almost $50 \%$ of lenders were in the Greater Jakarta area (Financial Services Authority, 2019). This research used data collection methods collected by distributing online questionnaires. Samples from the study were addressed to individuals who met the criteria already mentioned in non-contrived situations. Samples were chosen using the Convenience Sampling technique. To analyzing obtained data, this study used the PLS-SEM method. This method was used because this research was an extension of a pre-existing theory, namely TAM, which was applied to a new technology namely P2P lending (Hair et al., 2011). Recommended sample size for this study is ten times of the amount of hypothesis in this study, which is 80 . But to get greater accuracy of data, we decided to increase this number to 125 sample targets.

\section{RESULTS AND DISCUSSION}

There were 200 questionnaires data distributed, with 135 returned or filled out by respondents. Table 1 shows demographics of the respondents who filled out the questionnaire provided.

Table 1: Demographics of Respondents

\begin{tabular}{|c|c|c|}
\hline Information & Frequency & Percentage \\
\hline \multicolumn{3}{|l|}{ Gender } \\
\hline Male & 76 & $56.3 \%$ \\
\hline Female & 59 & $43.7 \%$ \\
\hline \multicolumn{3}{|l|}{ Age } \\
\hline$<21$ years old & 8 & $5.9 \%$ \\
\hline 21 - 30 years old & 76 & $56.3 \%$ \\
\hline 31 - 50 years old & 50 & $37 \%$ \\
\hline$>50$ years old & 1 & $0.7 \%$ \\
\hline \multicolumn{3}{|l|}{ Marital Status } \\
\hline Married & 77 & $57 \%$ \\
\hline Unmarried & 58 & $43 \%$ \\
\hline \multicolumn{3}{|l|}{ Last Education } \\
\hline Undergraduate & 12 & $8.9 \%$ \\
\hline Graduate & 81 & $60 \%$ \\
\hline Postgraduate & 41 & $30.4 \%$ \\
\hline Others & 1 & $0.7 \%$ \\
\hline \multicolumn{3}{|l|}{ Profession } \\
\hline Entrepreneur & 15 & $11.1 \%$ \\
\hline Private Employee & 88 & $65.2 \%$ \\
\hline Government Employee & 15 & $11.1 \%$ \\
\hline Professional & 15 & $11.1 \%$ \\
\hline Others & 2 & $1.4 \%$ \\
\hline $\begin{array}{l}\text { Average Income (3 months } \\
\text { past) }\end{array}$ & & \\
\hline$<$ Rp. $5,000,000$ & 14 & $10.4 \%$ \\
\hline Rp. 5,000,000 - Rp. 1,.000,000 & 60 & $44.4 \%$ \\
\hline $\begin{array}{l}\mathrm{Rp}_{15,000,000} 10,000,001 \quad- \\
\mathrm{Rp} .\end{array}$ & 35 & $25.9 \%$ \\
\hline
\end{tabular}




\begin{tabular}{|c|c|c|}
\hline $\begin{array}{l}\text { Rp. } \quad 15,000,001- \\
20,000,000\end{array}$ & 13 & $9.6 \%$ \\
\hline$>$ Rp. $20,000,000$ & 13 & $9.6 \%$ \\
\hline \multicolumn{3}{|l|}{$\begin{array}{l}\text { Investment intensity in } P 2 P \\
\text { lending (past } 1 \text { year) }\end{array}$} \\
\hline 1 time & 47 & $34.8 \%$ \\
\hline 1 - 3 times & 64 & $47.4 \%$ \\
\hline$>3$ times & 24 & $17.8 \%$ \\
\hline \multicolumn{3}{|l|}{ The most used platform } \\
\hline Investree & 44 & $32.6 \%$ \\
\hline Amartha & 23 & $17 \%$ \\
\hline Danamas & 14 & $10.4 \%$ \\
\hline Koinworks & 14 & $10.4 \%$ \\
\hline Uang Teman & 21 & $15.6 \%$ \\
\hline Modal Rakyat & 14 & $10.4 \%$ \\
\hline Others & 5 & $3.7 \%$ \\
\hline \multicolumn{3}{|l|}{$\begin{array}{l}\text { Have you ever played a role as } \\
\text { borrower in P2P lending? }\end{array}$} \\
\hline Yes & 92 & $68.1 \%$ \\
\hline No & 43 & $31.9 \%$ \\
\hline \multicolumn{3}{|l|}{$\begin{array}{l}\text { Duration of use of } \\
\text { lending }\end{array}$} \\
\hline$<3$ months & 25 & $18.5 \%$ \\
\hline 3 - 6 months & 36 & $26.7 \%$ \\
\hline $6-12$ months & 69 & $51.1 \%$ \\
\hline $12-24$ months & 5 & $3.7 \%$ \\
\hline
\end{tabular}

Before the data can be processed, it was necessary to conduct two tests on the components used in the research, namely the validity test and the reliability test. A validity test was conducted to ensure that the components used in the research have relationships, and between one component construct and another construct do not have in common. To conduct validity testing, this study applied a convergent validity test and a discriminant validity test on the components of the questionnaire given (Drost, 2011). Convergence testing is done by testing the factor loading value of each component of the questionnaire, where the value of factor loading must exceed or be equal to 0.7 (Kay, 2013; Hair et al., 2011). Discriminant validity test is a test conducted to ensure that the variables used are unique and represent things that do not exist in other variables (Hair et al., 2011). Table 3 shows the results of the discriminant validity test of the variables tested in this study. The reliability test aimed to test consistency of data in the research component. Reliability testing was carried out by measuring Average Variance Extracted (AVE) and Composite Reliability (CR), where the component would be deemed to have passed if it had an AVE value exceeding or equal to 0.5 and $\mathrm{CR}$ exceeding or equal to 0.7 (Hair et al. ., 2011). Table 2 shows the results of the convergent validity and reliability tests of the research points used:

Table 2: Convergent and Reliability Validity Test Results

\begin{tabular}{|c|c|c|c|c|}
\hline Variable & Item & $\begin{array}{l}\text { Factor } \\
\text { Loading }\end{array}$ & $\mathbf{C R}$ & AVE \\
\hline \multirow{3}{*}{$\begin{array}{l}\text { Perceived Intermediary } \\
\text { Trust (PIT) }\end{array}$} & PIT1 & 0.795 & \multirow{3}{*}{0.818} & \multirow{3}{*}{0.601} \\
\hline & PIT2 & 0.729 & & \\
\hline & PIT3 & 0.799 & & \\
\hline \multirow{3}{*}{$\begin{array}{l}\text { Perceived } \\
\text { Trust (PBT) }\end{array}$} & PBT1 & 0.814 & \multirow{3}{*}{0.812} & \multirow{3}{*}{0.592} \\
\hline & PBT2 & 0.788 & & \\
\hline & PBT3 & 0.701 & & \\
\hline \multirow{2}{*}{ Perceived Benefit (PB) } & PB1 & 0.87 & \multirow{2}{*}{0.83} & \multirow{2}{*}{0.71} \\
\hline & PB2 & 0.814 & & \\
\hline \multirow{3}{*}{$\begin{array}{l}\text { Perceived Ease of Use } \\
\text { (PEU) }\end{array}$} & PEU1 & 0.81 & \multirow{3}{*}{0.861} & \multirow{3}{*}{0.675} \\
\hline & PEU2 & 0.867 & & \\
\hline & PEU3 & 0.785 & & \\
\hline \multirow{3}{*}{$\begin{array}{l}\text { Perceived } \\
\text { (PU) }\end{array}$} & PU1 & 0.854 & \multirow{3}{*}{0.891} & \multirow{3}{*}{0.732} \\
\hline & PU2 & 0.859 & & \\
\hline & PU3 & 0.854 & & \\
\hline \multirow{3}{*}{$\begin{array}{l}\text { Attitude } \quad \text { Towards } \\
\text { Behavior (ATT) }\end{array}$} & ATT1 & 0.848 & \multirow{3}{*}{0.883} & \multirow{3}{*}{0.716} \\
\hline & ATT2 & 0.864 & & \\
\hline & ATT3 & 0.826 & & \\
\hline \multirow{3}{*}{ Intention to Use (INT) } & INT1 & 0.89 & \multirow{3}{*}{0.909} & \multirow{3}{*}{0.769} \\
\hline & INT2 & 0.869 & & \\
\hline & INT3 & 0.873 & & \\
\hline
\end{tabular}


Table 3: Discriminant Test Results

\begin{tabular}{|c|c|c|c|c|c|c|c|}
\hline & ATT & INT & PB & PBT & PEU & PIT & PU \\
\hline $\begin{array}{l}\text { AT } \\
\mathrm{T}\end{array}$ & $\begin{array}{l}0.84 \\
6\end{array}$ & & & & & & \\
\hline INT & 0.75 & $\begin{array}{l}0.87 \\
7\end{array}$ & & & & & \\
\hline PB & $\begin{array}{l}0.45 \\
3 \\
\end{array}$ & $\begin{array}{l}0.42 \\
1\end{array}$ & $\begin{array}{l}0.84 \\
2\end{array}$ & & & & \\
\hline $\begin{array}{l}\mathrm{PB} \\
\mathrm{T}\end{array}$ & 0.51 & 0.56 & $\begin{array}{l}0.41 \\
8\end{array}$ & $\begin{array}{l}0.76 \\
9\end{array}$ & & & \\
\hline $\begin{array}{l}\mathrm{PE} \\
\mathrm{U}\end{array}$ & $\begin{array}{l}0.51 \\
6 \\
\end{array}$ & $\begin{array}{l}0.53 \\
6 \\
\end{array}$ & 0.61 & $\begin{array}{l}0.67 \\
1 \\
\end{array}$ & $\begin{array}{l}0.82 \\
2 \\
\end{array}$ & & \\
\hline PIT & $\begin{array}{l}0.61 \\
1\end{array}$ & 0.56 & $\begin{array}{l}0.38 \\
4\end{array}$ & $\begin{array}{l}0.55 \\
2 \\
\end{array}$ & $\begin{array}{l}0.51 \\
8 \\
\end{array}$ & $\begin{array}{l}0.77 \\
5\end{array}$ & \\
\hline PU & $\begin{array}{l}0.68 \\
7\end{array}$ & $\begin{array}{l}0.63 \\
8\end{array}$ & $\begin{array}{l}0.58 \\
1\end{array}$ & 0.62 & $\begin{array}{l}0.63 \\
2\end{array}$ & $\begin{array}{l}0.59 \\
9\end{array}$ & $\begin{array}{l}0.85 \\
6\end{array}$ \\
\hline
\end{tabular}

Information:

PIT = Perceived Intermediary Trust

$\mathrm{PBT}=$ Perceived borrower Trust

$\mathrm{PB}=$ Perceived Benefit

$\mathrm{PEU}=$ Perceived Ease of Use

$\mathrm{PU}=$ Perceived Usefulness

ATT $=$ Attitude Towards Behavior

INT $=$ Intention to Use

In the Smart PLS application, an evaluation of the structure of the model was carried out using the bootstrapping process, where the bootstrap sample process was conducted with a total of 5000 sample data (Wong, 2013). In conducting a hypothesis test, by determining the significance level value at $5 \%$, the hypothesis would be acceptable if the t-value was above 1.96 or the p-value was smaller or equal to 0.05 (Hair et al., 2011). Table 4 shows bootstrapping process result between variables used in the research. Figure 2 shows calculation result on described research model.

Table 4. Bootstrapping Process Results

\begin{tabular}{llllll}
\hline Hypotheses & Path & $\begin{array}{l}\text { Path } \\
\text { Coefficient }\end{array}$ & $\boldsymbol{T}$-Statistics & $\boldsymbol{P}$-value & $\mathbf{R} \boldsymbol{}$ \\
\hline H1 & PIT $\rightarrow$ PBT & 0.552 & 9.158 & 0 & $\mathrm{Ac}$ \\
\hline H2 & PIT $\rightarrow$ ATT & 0.293 & 3.327 & 0.001 & $\mathrm{Ac}$ \\
\hline H3 & PBT $\rightarrow$ ATT & 0.03 & 0.328 & 0.743 & $\mathrm{Re}$ \\
\hline H4 & PB $\rightarrow$ ATT & 0.05 & 0.527 & 0.598 & $\mathrm{Re}$ \\
\hline H5 & PEU $\rightarrow$ PU & 0.632 & 10.638 & 0 & $\mathrm{Ac}$ \\
\hline H6 & PEU $\rightarrow$ ATT & 0.033 & 0.296 & 0.768 & R \\
\hline H7 & PU $\rightarrow$ ATT & 0.443 & 4.656 & 0 & $\mathrm{~A}^{\mathrm{T}}$ \\
\hline H8 & ATT $\rightarrow$ INT & 0.75 & 17.934 & 0 & $\mathrm{~A}^{\prime}$ \\
\hline
\end{tabular}

Information:

PIT= Perceived Intermediary Trust

PBT $=$ Perceived borrower Trust

$\mathrm{PB}=$ Perceived Benefit

$\mathrm{PEU}=$ Perceived Ease of Use

$\mathrm{PU}=$ Perceived Usefulness

ATT $=$ Attitude Towards Behavior

INT = Intention to Use

Some interesting things can be seen from the results of this study, such as the significant factors which determine attitudes towards investment on the $\mathrm{P} 2 \mathrm{P}$ loan platform, namely perceived intermediary trust (PIT) and perceived usefulness (PU). Indicators that place importance on the level of trust of prospective lenders in a platform are perceptions of the need for protection and policies that support the interests of fund borrowers. These results follow previous studies that have the results of the study (Chen et al., 2014; Puteri et al., 2018). Perception of the use of $\mathrm{P} 2 \mathrm{P}$ loans and prioritizing in increasing income in investing also has a significant influence on attitudes towards P2P loans. Some of the causes of this result are issued in the investment process on $\mathrm{P} 2 \mathrm{P}$ loans, where the lender does not need to check in its entirety, unlike some other investment instruments such as stocks. This result is also supported by previous studies (Lee, 2017; Yu et al., 2018).

This study also found that perceived borrower trust does not significantly influence attitudes towards P2P lending. These results contradict the results of other studies that tested the P2P lending key factor (Yang \& Lee, 2016; Chen et al., 2014). However, other research that uses a sample of $\mathrm{P} 2 \mathrm{P}$ platform users in Indonesia states that the perceived borrower trust has no significant influence in determining attitudes towards P2P lending (Puteri et al., 2018). One possibility that may cause this is the ease of the registration process and the credit survey process on $\mathrm{P} 2 \mathrm{P}$ platforms in Indonesia, so borrowers can register on several $\mathrm{P} 2 \mathrm{P}$ lending platforms at once. This causes the level of lender confidence in the borrower of funds to be less influential forP2P lending in Indonesia.

This study also shows that perceived benefit does not have

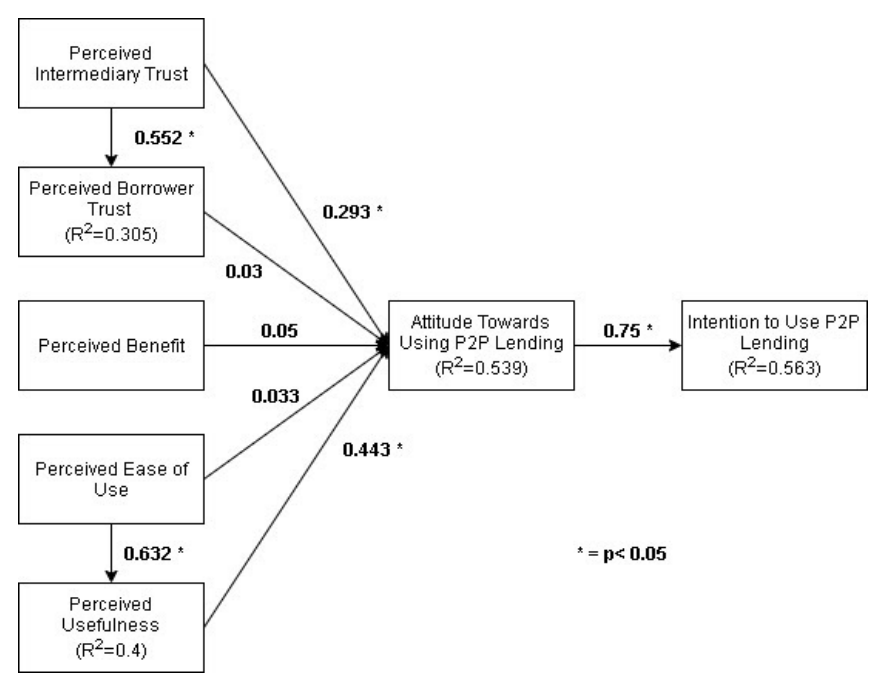

Figure 2: Results

Acucpucu

Rejectedficant effect on attitudes towards P2P lending. The Accepted of other studies give different results compared to the

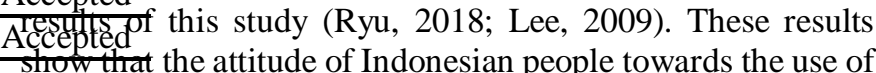
$\mathrm{P} 2 \mathrm{P}$ lending is quite positive, but the key cause is not derived from the perception of the benefits that can be achieved or the opportunity to lend funds to others. Meanwhile, perceived ease of use does not have a significant effect on attitudes towards P2P lending. These results do not follow the results of other studies that show the opposite (Lee, 2017). This possibility is caused by the majority of the respondents from data obtained being under the age of 30 , a generation that is more familiar with the use of information technology systems such as P2P lending, that making ease of use not become a significant indicator that influences attitudes towards investing in $\mathrm{P} 2 \mathrm{P}$ lending. 
On the other hand, perceived intermediary trust has a significant influence on the perceived borrower trust. These results follow other studies that discuss P2P lending (Puteri et al., 2018; Chen et al., 2014; Zhang et al., 2014). In other words, this research shows that prospective lender ratings of the platform are sufficient to represent their perceptions of the perceptions of borrowers on the platform. One of the actions that can be taken is to focusing on the quality of the P2P lending platform, especially in terms of transparency of borrowers' data. This can be one of the things that can be considered to increase lender's confidence and trust to the platform because focusing on other things such as increasing trust in borrowers does not provide significant results on investment intentions.

Although perceived ease of use does not have a direct impact on attitudes towards P2P lending, perceived ease of use has a significant impact in determining perceived usefulness on the use of P2P lending. Other studies that using TAM in determining the relation of these variables also had similar results (Van der Heijden et al., 2003). In general, ease of use of a system is not a critical factor for determining investment intentions, but the use of an easy system is one of the keys to making lenders able to know the usefulness of the system more quickly and easily. If prospective lenders can understand the usability of the system easily, then this can have an impact on attitudes towards the P2P lending system, as explained in the previous hypothesis.

A positive attitude towards investing in $\mathrm{P} 2 \mathrm{P}$ lending has a significant impact on the intention to invest in $\mathrm{P} 2 \mathrm{P}$ lending platform. This finding follows previous studies that concur (Chen et al., 2014; Lee, 2017; Van der Heijden et al., 2003; $\mathrm{Yu}$ et al., 2018). These results indicate that the use of TAM in context is still valid to be used to find the cause of acceptance of a new system. In the future, TAM will still be widely used due to the rapid development of technology that will give birth to many new forms of technology that are engaged in various fields.

\section{CONCLUSION}

Based on the data and analysis that has been presented, two important factors that influence an investor's desire to lend funds to P2P lending are perception of the platform and perception of usefulness that can be attained from $\mathrm{P} 2 \mathrm{P}$ lending. The ease of lending inP2P lending and the nature of this investment instrument that does not require periodic checking are some factors that make $\mathrm{P} 2 \mathrm{P}$ lending superior. Perceived borrower trust, perceived benefit, and perceived ease of use are not significant factors that determine the desire to invest in the P2P lending platform in Indonesia. The perception of investor benefit protection implemented by the $\mathrm{P} 2 \mathrm{P}$ lending platform is an important element that can be used by $\mathrm{P} 2 \mathrm{P}$ lending platforms. Therefore, a P2P platform can focus on policies that benefit lenders and creates a good user experience to be able to attract the interest of prospective lenders to use $\mathrm{P} 2 \mathrm{P}$ lending.

\section{MANAGERIAL IMPLICATIONS}

The results showed that perceived intermediary trust was a factor that influence attitudes towards the use of P2P lending. Some points that are known to influence the intermediary trust from this research are the platform's commitment to protecting the interests and profits achieved by investors. Therefore, one of the actions that can be taken by practitioners in this field is to build a brand image and values that are lender oriented. Related research states that one way to gain trust is to provide transparency and completeness of information, specifically related to the system and the borrower (Chen et al., 2014). Some examples of implementation that can be conducted are making transparent SOPs, such as clarity of information in profit sharing, risk exposure that is easily understood, along with clarity of the value of the benefits obtained.

One of the other points found in this study is perceived ease of use has no significant effect on attitude but has a significant effect on perceived usefulness. Conclusion that can be drawn from these results and considered by management is the importance of the user experience factor in creating a $\mathrm{P} 2 \mathrm{P}$ lending platform. Other studies also have one practical implication that states that increasing perceived ease of use has great impact on creating positive attitudes towards P2P lending (Li et al., 2016). To get a good user experience, creating a simple and easy user interface is understood to be important. P2P lending is a business field that has many regulations and ways of operation that need to be explained because this concept is not yet too prevalent in the community. One example of an implementation that can be conducted is by presenting content in the form of visual illustrations because at present the tendency of regulations and standards that are made are still displayed in text form, making it less attractive to prospective lenders to read and understand the applicable SOP. Another form of implementation that can be done is by automation that can simplify the process of registering and borrowing funds, to improve user experience.

\section{LIMITATIONS AND ADVICE}

This research has several limitations that can be used as prompts for further research. First, in addition to the behavior of the lenders studied, research related to key drivers for using $\mathrm{P} 2 \mathrm{P}$ lending from the borrower side can be conducted. The key drivers that determine the intention to invest in $\mathrm{P} 2 \mathrm{P}$ lending can change if this research is tested in different environments such as countries, cultures, and economic strata. Additions to the tested variables can also better understand the impact of key drivers that determine the intention to invest in $\mathrm{P} 2 \mathrm{P}$ lending.

\section{REFERENCES}

[1] Abubakar, L., \& Handayani, T. (2018, July). Financial technology: Legal challenges for Indonesia financial sector. In IOP Conference Series: Earth and Environmental Science (Vol. 175, No. 1, p. 012204). IOP Publishing. 
[2] Akturan, U., \& Tezcan, N. (2012). Mobile banking adoption of the youth market: Perceptions and intentions. Marketing Intelligence \& Planning, 30(4), 444-459.

[3] Amin, M. K., \& Li, J. (2014, June). Applying Farmer Technology Acceptance Model to Understand Farmer's Behavior Intention to use ICT Based Microfinance platform: A Comparative analysis between Bangladesh and China. In WHICEB (p. 31).

[4] Bae, S. Y., \& Han, J. H. (2020). Considering Cultural Consonance in Trustworthiness of Online Hotel Reviews among Generation $Y$ for Sustainable Tourism: An Extended TAM Model. Sustainability, 12(7), 2942.

[5] Chen, D., Lai, F., \& Lin, Z. (2014). A trust model for online peer-to-peer lending: a lender's perspective. Information Technology and Management, 15(4), 239-254.

[6] Chuang, L. M., Liu, C. C., \& Kao, H. K. (2016). The adoption of fintech service: TAM perspective. International Journal of Management and Administrative Sciences, 3(7), 1-15.

[7] Davis, F. D. (1985). A technology acceptance model for empirically testing new end-user information systems: Theory and results (Doctoral dissertation, Massachusetts Institute of Technology).

[8] Davis, F. D. (1989). Perceived usefulness, perceived ease of use, and user acceptance of information technology. MIS quarterly, 319-340.

[9] Drost, E. A. (2011). Validity and reliability in social science research. Education Research and perspectives, 38(1), 105.

[10] Eastlick, M. A., Lotz, S. L., \& Warrington, P. (2006). Understanding online B-to-C relationships: An integrated model of privacy concerns, trust, and commitment. Journal of Business Research, 59(8), 877-886.

[11] Fathema, N., Shannon, D., \& Ross, M. (2015). Expanding the Technology Acceptance Model (TAM) to examine faculty use of Learning Management Systems (LMSs) in higher education institutions. Journal of Online Learning \& Teaching, 11(2).

[12] Hackbarth, G., Grover, V., \& Mun, Y. Y. (2003). Computer playfulness and anxiety: positive and negative mediators of the system experience effect on perceived ease of use. Information \& management, 40(3), 221-232.

[13] Hair, J. F., Ringle, C. M., \& Sarstedt, M. (2011). PLS-SEM: Indeed a silver bullet. Journal of Marketing Theory and Practice, 19(2), 139-152.

[14] Hendriyani, C., \& Raharja, S. U. J. (2019). Business Agility Strategy: peer-to-peerlending of Fintech Startup in the Era of Digital Finance in Indonesia. Review of Integrative Business and Economics Research, 8, 239-246.

[15] Huei, C. T., Cheng, L. S., Seong, L. C., Khin, A. A., \& Bin, R. L. L. (2018). Preliminary Study on consumer attitude towards FinTech products and services in Malaysia. International Journal of Engineering \& Technology, 7(2.29), 166-169.

[16] Iman, N. (2018). Assessing the dynamics of fintech in Indonesia. Investment Management and Financial Innovations, 15(4), 296-303.
[17] Kay Wong. (2013). Partial Least Squares Structural Equation Modeling (PLS-SEM) Techniques Using Smart PLS. Journal of Marketing Bulletin, Vol. 24, 2013.

[18] Kim C, Tao W, Shin N, Kim KS (2010) An empirical study of customers' perceptions of security and trust in e-payment systems. Electron Commer Res Appl 9(1):84-95

[19] Klafft, M. (2008, July). Online peer-to-peer lending: a lenders' perspective. In Proceedings of the international conference on E-learning, E-business, enterprise information systems, and E-government, EEE (pp. 371-375)

[20] Kleivene, L. E. (2018). P2P Mobile Payments: Investigating the Factors of Adoption Among Students in Germany. In Omni channel Branding (pp. 45-67). Springer Gabler, Wiesbaden.

[21] Lee, S. (2017). Evaluation of Mobile Application in User's Perspective: Case of P2P lending Apps in FinTech Industry. TIIS, 11(2), 1105-1117.

[22] Lee, M. C. (2009). Factors influencing the adoption of internet banking: An integration of TAM and TPB with perceived risk and perceived benefit. Electronic commerce research and applications, 8(3), 130-141.

[23] Lee, Y. H., Hsieh, Y. C., \& Chen, Y. H. (2013). An investigation of employees' use of e-learning systems: applying the technology acceptance model. Behaviour \& Information Technology, 32(2), 173-189.

[24] Li, J., Zheng, H., Kang, M., Wang, T., \& Chen, S. (2016, June). Understanding Investment Intention towards P2P lending: an Empirical Study. In PACIS (p. 82).

[25] Lim, K. H., Sia, C. L., Lee, M. K., \& Benbasat, I. (2006). Do I trust you online, and if so, will I buy? An empirical study of two trust-building strategies. Journal of management information systems, 23(2), 233-266.

[26] Limbu, Y. B., Wolf, M., \& Lunsford, D. (2012). Perceived ethics of online retailers and consumer behavioral intentions: The mediating roles of trust and attitude. Journal of Research in Interactive Marketing, 6(2), 133-154.

[27] Milne, A., \& Parboteeah, P. (2016). The business models and economics of peer-to-peer lending.

[28] Mou, J., Shin, D. H., \& Cohen, J. (2017). Understanding trust and perceived usefulness in the consumer acceptance of an e-service: a longitudinal investigation. Behaviour \& Information Technology, 36(2), 125-139.

[29] Nanggong, A. (2019). Perceived Benefit, Environmental Concern and Sustainable Customer Behavior on Technology Adoption. The Asian Journal of Technology Management, 12(1), 31-47.

[30] Otoritas Jasa Keuangan (2019, July). Perkembangan Fintech lending. Retrieved from https://www.ojk.go.id/id/kanal/iknb/data-dan-statistik/fint ech/Documents/Perkembangan \%20Fintech\%20lending\% 20Periode\%20Juni\%202019.pdf

[31] Pavlou PA (2003) Consumer acceptance of electronic commerce: Integrating trust and risk with the technology acceptance model. Int J Electron Commer 7(3):101-134 
[32] Pramana, I. W. B., Atmadja, I. B. P., \& Sutama, I. B. P. (2018). Peranan Otoritas Jasa Keuangan Dalam Mengawasi Lembaga Keuangan Non-Bank Berbasis Financial Technology Jenis peertopeerlending. Kertha Semaya: Journal Ilmu Hukum, 1-14.

[33] Puteri, F. S., Handayani, P. W., Azzahro, F., \& Pinem, A. A. (2018, September). Analysis of Investor Intention to Invest Capital in Small and Medium Enterprises Through peer-to-peerlending in Indonesia. In 2018 International Conference on Computing, Engineering, and Design (ICCED) (pp. 87-92). IEEE.

[34] Radnan, P. Y., \& Purba, J. T. (2018). The use of Information Communication Technology (ICT) as the Technology Acceptance Model (TAM) of Mobile Banking. Jurnal Manajemen dan Pemasaran Jasa, 9(2), 283-298.

[35] Ryu, H. S. (2018, January). Understanding benefit and risk framework of fintech adoption: comparison of early adopters and late adopters. In Proceedings of the 51st Hawaii International Conference on System Sciences.

[36] Salloum, S. A., \& Al-Emran, M. (2018). Factors affecting the adoption of E-payment systems by university students: Extending the TAM with trust. International Journal of Electronic Business, 14(4), 371-390.

[37] Sánchez-Prieto, J. C., Olmos-Migueláñez, S., \& García-Peñalvo, F. J. (2017). MLearning and pre-service teachers: An assessment of the behavioral intention using an expanded TAM model. Computers in Human Behavior, 72, 644-654.

[38] Sari, A. R. (2018). Perlindungan Hukum Bagi Pemberi Pinjaman Dalam Penyelenggaraan Financial Technology Berbasis peertopeerlending Di Indonesia.

[39] Schueffel, P. (2016). Taming the beast: a scientific definition of fintech. Available at SSRN 3097312.

[40] Sensuse, D. I., \& Napitupulu, D. (2017). The study of user acceptance toward E-learning System in Higher Education. Indonesian Journal of Electrical Engineering and Computer Science, 7(2), 466-473.

[41] Sohn, S. (2017). A contextual perspective on consumers' perceived usefulness: The case of mobile online shopping. Journal of Retailing and Consumer Services, 38, 22-33.

[42] Sukmaningsih, D. W. (2018). A model for lender-borrower trust in peer-to-peer lending. ComTech: Computer, Mathematics and Engineering Applications, 9(1), 15-24.

[43] Sundjaja, A. M., \& Tina, A. (2019). The factors of the intention to use P2P lending Financial Technology (Fintech) website at Jadetabek intervening by perceived value. International Journal of Recent Technology and Engineering (IJRTE), 8(3), 3102-3107.

[44] Suyanto, S., \& Kurniawan, T. A. (2019). Faktor yang Mempengaruhi Tingkat Kepercayaan Penggunaan FinTech pada UMKM Dengan Menggunakan Technology Acceptance Model (TAM). AKMENIKA, 16(1).

[45] Tampubolon, H. R. (2019). SELUK-BELUK PEER TO PEER LENDING SEBAGAI WUJUD BARU KEUANGAN DI INDONESIA. Jurnal Bina Mulia Hukum, 3(2), 188-198.
[46] Tandiono, J., Djojo, B. W., Candra, S., \& Heriyati, P. (2020). Finding Customer Perception of Peer-to-Peer (P2P) Lending Financial Technology in Pohon Dana. Binus Business Review, 11(1), 51-58.

[47] Tanduklangi, A. (2017). Determinants of User Intention in Using e-Learning Technology in Indonesian Context: An Empirical Study. Mediterranean Journal of Social Sciences, 8(3), 69-77.

[48] Teo, T., \& Zhou, M. (2014). Explaining the intention to use technology among university students: a structural equation modeling approach. Journal of Computing in Higher education, 26(2), 124-142.

[49] Thaker, M. A. B. M. T., Thaker, H. B. M. T., \& Rahman, M. P. B. (2019). Factors Affecting Investors' Intention to Invest in a peer-to-peer lending platform in Malaysia: An Extended Technology Acceptance Model.

[50] Van der Heijden, H., Verhagen, T., \& Creemers, M. (2003). Understanding online purchase intentions: contributions from technology and trust perspectives. European journal of information systems, 12(1), 41-48.

[51] Venkatesh, V., \& Davis, F. D. (2000). A theoretical extension of the technology acceptance model: Four longitudinal field studies. Management science, 46(2), 186-204.

[52] Verhagen, T., Meents, S., \& Tan, Y. H. (2006). Perceived risk and trust associated with purchasing at electronic marketplaces. European Journal of information systems, 15(6), 542-555.

[53] Wang, M., Wang, T., Kang, M., \& Sun, S. (2014). Understanding Perceived platform Trust and Institutional Risk in Peer-to-peer Lending platforms from Cognition-Based and Affect-Based Perspectives. In PACIS (p. 208).

[54] Weng, F., Yang, R. J., Ho, H. J., \& Su, H. M. (2018). A TAM-based study of the attitude towards use intention of multimedia among schoolteachers. Applied System Innovation, 1(3), 36.

[55] Wu, B., \& Chen, X. (2017). Continuance intention to use MOOCs: Integrating the technology acceptance model (TAM) and task technology fit (TTF) model. Computers in Human Behavior, 67, 221-232.

[56] Yang, Q., \& Lee, Y. C. (2016, August). Critical factors of the lending intention of online P2P: moderating role of perceived benefit. In Proceedings of the 18th Annual International Conference on Electronic Commerce: e-Commerce in Smart connected World (p. 15). ACM.

[57] Yang, Q., \& Lee, Y. C. (2016). Influencing factors on the lending intention of online peer-to-peer lending: Lessons from renrendai. com. The Journal of information systems, 25(2), 79-110.

[58] Yu, Y., Yi, W., Feng, Y., \& Liu, J. (2018, January). Understanding the intention to use commercial bike-sharing systems: an integration of TAM and TPB. In Proceedings of the 51st Hawaii International Conference on System Sciences.

[59] Zhang, T., Tang, M., Lu, Y., \& Dong, D. (2014). Trust building in online peer-to-peer lending. Journal of Global Information Technology Management, 17(4), 250-266. 